\section{ADMISSION OF THE PRINCE OF WALES TO THE HONORARY FELLOWSHIP OF THE ROYAL COLLEGE OF SURGEONS OF ENGLAND.}

A DEPUtation consisting of Sir William Mac Cormac, Bart., K.C.V.O., the President of the College; Mr. John Langton, F.R.C.S. Eng., Mr. Henry Morris, F.R.C.S. Eng., Vice-presidents; Mr. Thomas Bryant, F.R.C.S. Eng., past President and Senior Member of Council; Mr. Edward Trimmer, M.A., the Secretary ; and Mr. Sibert Cowell, B.A., the assistant secretary, attended by appointment on Tuesday, July 24th, at Marlborough House for the purpose of presenting to the Prince of Wales the diploma of the Honorary Fellowship of the College to which His Royal Highness was elected on June 14th, 1900.

Sir William Mac CoBmac, after introducing the members of the deputation, addressed His Royal Highness as follows :-

YOUR ROYAL HIGHNESS, - It is my great pleasure and privilege to-day, as President of the Royal College of Surgeons of England, to confer upon your Royal Highness the title and distinction of Honorary Fellow of our College. When this question was first mooted, nearly three years ago, we discovered that we did not possess the power to confer any honorary degree. Since then a new Charter has been procured and Your Royal Highness having graciously acceded to our wishes that you should become associated with our Corporation, I now in the name and by the authority of the Royal College of Surgeons of England, admit you an Honorary Fellow of the College.

And now, Sir, that you have become a Fellow of our College, permit me to tender to you our most respectful congratulations. You have on many occasions shown your interest and sympathy with our work, and what has happened to.day is not likely to diminish that interest. We are sure that the intimate association of your illustrious name with our College is an event in its history of the greatest importance, and cannot fail to be an encouragement in the future to all those who are connected with it.

Sir William MacCormac then handed to the Prince a Diploma on vellum engraved with the College arms, impressed with the College seal, and inscribed in the following terms :-

"Know all Men by these Presents that We, the Royal Oollege of Surgeons of England, do hereby admit His Royal Highness Albert Edward, Prince of Wales, Duke of Cornwall, K.G., \&c., \&c., \&c., \&c., an Honorary Fellow of the College. "As Witness our Common Seal this fourteenth day of June, 1900.

"William Mac Cormac, President.

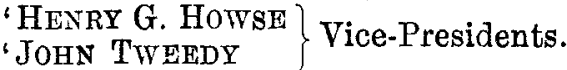

"Enrolled by EDWARD TRIMMer, Secretary."

The Prince having accepted the Diploma expressed in courteous terms the pleasure it gave him to become an Honorary Fellow of the Royal College of Surgeons, the centenary of which was about to be celebrated. His Royal Highness, as the first Honorary Fellow of the College, having signed his name on the "Roll of Honorary Fellows," afterwards took leave of the President and officers, and the deputation withdrew.

\section{FACTORIES AND WORKSHOPS IN 1899.}

I.

THE exhaustive annual report of the Chief Inspector of Factories and Workshops for the year 1899 has just been issued by the Home Office and contains, as usual, much that will repay pernsal by those interested in the health of the community and the means taken to safeguard it. Dr. Arthur Whitelegge, the chief inspector, in his interesting summary of the year's work of his department, tells us that 1899 was a busy year with many changes. Trade generally was active, involving the registration and inspection of more premises and an increase in the number of accidents to be investigated, heavier lists of casualties being always expected in times of industrial activity. With regard to these we find from a table appended that the accidents reported to certifying surgeons under the Factory and Workshop Act amounted in 1897 to 15,985 , in 1898 to 19,227 , and in 1899 to 22,771 , these totals including fatal and non-fatal accidents occurring to both male and female workers; while the 22,771 accidents of 1899 include 871 fatal acc:dents, 858 to males and 13 to females, and the 21,900 non-fatal accidents for the same year comprise 18,758 to males and 3142 to females. These figures give some idea of the relative amount of danger from accidents which is run by the two sexes in our trades and manufactures. We note with regret that a decrease in accidents to children observed in 1897-98 was not continued, there being, on the contrary, some increase in 1898-99. Dr. Whitelegge further points out that while the minor accidents reportable only to the inspectors increased 25.2 per cent., from 38,335 to 47,989 , the number reported also to certifying surgeons advanced 18.4 per cent., from 19,227 to 22,771 , and the fatal accidents $19 \cdot 8$ per cent., from 727 to 871 . On the whole, therefore, he observes, the increase was less marked in the more severe forms of injury, but only under the head of "Loss of sight" was there actual decrease, and in that group the numbers are small, reference to the tables showing that loss of sight was recorded in 53 cases in 1898 and in 47 cases in 1899. With regard to the compulsory notification of certain forms of industrial poisoning under section 29 of the Factory and Workshop Act of 1895 the tables and details given show that cases of plumbism were on the whole fewer, which was mainly owing to the decrease in the number of cases reported as occurring in, and in connexion with, potteries. Under some of the sub-heads under which occur other trades in which lead in various forms is a source of danger diminution is also observable. Such subheads are "Glass-making," " File-cutting," and "Smelting." There was increase, however, in lead poisoning in some industries, especially in the manufacture of white lead and paints and colours, and in the misceilaneous group of minor lead industries. For the third year in succession there was no reported case of industrial arsenical poisoning. In the case of phosphorus necrosis also it is satisfactory to learn that fewer instances were reported, but anthrax seems to have increased and to have become unusually prevalent. Anthrax arises in dealing with horsehair, hides, and skins, and the degree of danger appears to vary markedly with the various sources from which these are imported, the worst country in respect of anthrax being conspicuously China. Mercurial poisoning occurs in the report for the first time, the Home Secretary having availed himself last year of the power given by Section 29 to place diseases traceable to mercurial poisoning in a factory or workshop among those of which notice must be given to his department.

The provisions of this Section of the Act of 1895 should be borne in mind by all medical men wherever practising. Those in large manufacturing centres are presumably familiar with them, but the medical inspector in his report in the Blue Book before us states that many elsewhere are not, such diseases as scarlet fever and their duties with regard to the notification of them being matters of everyday practice, while cases of lead poisoning are comparatively rare. The result of this is that the statistics with regard to lead poisoning are in some respects not to be relied upon as accurate or exhausive. We may mention that the 29th Section of the Factory and Workshop Act of 1895 provides that every medical practitioner attending or called in to visit a patient whom he believes to be suffering from lead, phosphorus, or arsenical poisoning or anthrax contracted in any factory or workshop, shall (unless the notice required by the Section has previously been sent) send to the Chief Inspector of Factories at the Home Office a notice stating the name and full postal address of the patient and the disease from which in the opinion of the medical practitioner the patient is suffering. The medical man duly giving this notice is entitled to a fee of $2 s .6 d$. to be paid by the Home Office; by neglecting to do so he is liable to a fine of $40 \mathrm{~s}$. Care must therefore be exercised not to omit reporting a case proper to be reported, but it must be borne in mind that the illness must have been contracted in a factory or 